\title{
The correlation of the antral follicle count and Serum anti-mullerian hormone
} Serum anti-mülleryan hormon ve antral folikül sayıst iliskisi

\author{
Behiye Pınar Göksedef, Nurettin Idiş, Hüsnü Görgen, Yaprak Rüstemoğlu Asma, Murat Api, Ahmet Çetin \\ Haseki Teaching and Research Hospital, Obstetrics and Gynecology, Istanbul, Turkey
}

\section{Abstract}

Objective: To compare the value of the basal serum anti-Müllerian hormone $(\mathrm{AMH})$ level with most of the established ovarian reserve tests.

Material and Methods: A total of 141 infertile women was studied prospectively. On cycle day 3, serum levels of AMH, inhibin B, estradiol (E), FSH and LH levels were measured, and the number of early antral follicles (2-6 mm in diameter) estimated at ultrasound scanning to compare the strengths of hormonal-follicular correlations.

Results: The mean age of the participants was 29.18 \pm 5.54 . The mean $\mathrm{AMH}$ and total AFC on day 3 were $2.23 \pm 1.90 \mathrm{ng} / \mathrm{ml}$ and $8.35 \pm 2.83$, respectively. Serum AMH levels were more tightly correlated $(\mathrm{p}<0.001)$ with number of the early antral follicle count $(r=0.467, p<0.0001)$ than age and serum levels of FSH $(r=-0.400, p<0.001 ; r=-0.299, p<0.001$ respectively). No correlation was detected between serum levels of inhibin $B, E_{2}$, and LH ( $r=0.154, p=0.06 ; p=0.31 ; r=-0.085$ and $r=0.067$, $\mathrm{p}=0.42$ ) and $\mathrm{AFC}$.

Conclusion: Serum AMH levels showed a strong correlation with $\mathrm{AFC}$, and also this correlation is stronger than the other ovarian reserve parameters. (J Turkish-German Gynecol Assoc 2010; 11: 212-5)

Key words: Anti-mullerian hormone; ovarian reserve; antral follicle count Received: 9 October, 2010

Accepted: 22 November, 2010

\section{Introduction}

Ovarian reserve is described as the quantity of the ovarian follicular cohort and quality of the oocytes (1). The assessment of the ovarian reserve needs for identification of the response of controlled ovarian stimulation $(\mathrm{COH})$. This assessment facilitates appropriate pretreatment counseling and modification of an individual $>s$ treatment protocol in an attempt to maximize their potential response. Assessing an individual's ovarian reserve includes age, estradiol $\left(\mathrm{E}_{2}\right)$ and basal folliclestimulating hormone (FSH) levels. Antral follicle count, serum inhibin B levels, ovarian volume, and vascular resistance have also been studied as markers of ovarian reserve. The antral follicle count (AFC) have been widely used as the ovarian reserve test, due to convenience of the ultrasonographic tools usage. Follicle counts can be performed easily with the help of the high quality resolution of the sonographic systems (2-10). Although there are well-known difficulties to obtain correct AFC such as high inter-observer differences and ana-
Özet

Amaç: Bu çalışmada basal serum bazal anti-Müllerian hormone $(\mathrm{AMH})$ seviyesinin diğer sık kullanılan over rezerv testleri ile karşılaştırılması amaçlanmıştır.

Gereç ve Yöntemler: Toplam 141 infertil kadın çalışmaya alındı. Üçüncü gün serum AMH, inhibin B, östradiol $\left(\mathrm{E}_{2}\right)$, FSH ve LH seviyeleri ölçümü ve ultrasonografik olarak erken antral folikül (2-6 mm çaplı) sayımı yapılarak hormonal-foliküler korelasyon değerlendirildi.

Bulgular: Olguların ortalama yaşı $29.18 \pm 5.54$ idi. Ortalama AMH ve total AFC sırasıly $2.23 \pm 1.90 \mathrm{ng} / \mathrm{ml}$ ve $8.35 \pm 2.83$ olarak saptandl. Serum AMH seviyesi ile erken antral folikül sayısı arasındaki korelasyon $(r=0.467, p<0.0001)$, yaş ve serum FSH düzeyileri ile erken antral folikül sayısı arasındaki korelasyondan (sırasıyla; $r=-0.400, p<0.001$; $r=0.299, p<0.001)$ daha güçlü idi $(p<0.001)$. Serum inhibin $B, E_{2}$, ve LH seviyeleri ile AFC arasında korelasyon saptanmadı $(r=0.154$, $\mathrm{p}=0.06 ; \mathrm{p}=0.31 ; \mathrm{r}=-0.085$ and $\mathrm{r}=0.067, \mathrm{p}=0.42$ ).

Sonuç: Serum AMH seviyesi, AFC ile sıkı bir biçimde ilişkilidir ve aynı zamanda bu ilişki diğer over rezervi değerlendirme parametrelerinden daha güçlüdür. (J Turkish-German Gynecol Assoc 2010; 11: 212-5) Anahtar kelimeler: Anti-mülleryan hormon; over reservi; antral folikül sayısı

Geliş Tarihi: 09 Ekim 2010

Kabul Tarihi: 22 Kasım 2010

tomical variations (3), it has been suggested that the ability of AFC to predict poor response might be significantly better than basal FSH. Thus, AFC has been considered the "test of first choice" by some investigators $(2,11)$.

Recently; serum anti-Mullerian hormone (AMH) has been commonly studied as a potential new test for ovarian reserve. $\mathrm{AMH}$, also known as Mullerian-inhibiting substance, is a dimeric glycoprotein that belongs to the transforming growth factor- $\beta$ family (12-15). Antimullerian hormone is secreted by small antral follicles and in reproductive-aged women and it is expressed by granulosa cells of the ovary (16). In the ovary, AMH inhibits initial primordial follicles recruitment and decreases the sensitivity of preantral and small antral follicles to FSH and hence suggesting its role in intrafollicular and interfollicular coordination of follicle development $(17,18)$. Recently it has been shown that the higher AMH levels were associated with the greater numbers of retrieved oocytes and improved embryo morphology in the IVF cycles $(10,15,19,20)$. There has been a controversary between the corelation of 
the $\mathrm{AFC}$ and the other ovarian reserve tests such as age, $\mathrm{AMH}$, basal FSH, $\mathrm{E}_{2}$ and inhibin-B. Therefore, the aim of this study is to investigate the correlation between $\mathrm{AFC}$ and age, $\mathrm{AMH}$, basal FSH, Estradiol $\left(\mathrm{E}_{2}\right)$, $\mathrm{LH}$ and inhibin-B levels in a selected population of women who were referred for the fertility treatment.

\section{Materials and Methods}

A total of 141 patients who were evaluated prior to their first treatment cycle were prospectively included into our study based on the following criteria: regular menstrual cycles (21-35 days), presence of both ovaries, age less than 45 years. Subjects were excluded if they had abnormal uterine bleeding, evidence of endocrine disorders (normal thyroid stimulating hormone, prolactin, testosterone and androstenedione), suboptimal visualization of the ovary by transvaginal ultrasonography, an ovarian cyst or follicle measuring $20 \mathrm{~mm}$ or more in diameter and a history of ovarian surgery. The Institutional Review Board approval and written informed consent were achieved for this study. On the third day of the spontaneous cycle, all patients had a transvaginal scan by the same investigator (N.I) using a GE General logiq 400 pro (GE medical systems, Korea CO., LTD. Sungdam Shi, KS) $5 \mathrm{MHZ}$ ultrasound probe to assess the number of antral follicles, measuring 2-6 mm, as described previously (3). Each ovary was measured in three planes and ovarian volume was calculated using the prolate ellipsoid formula (V=D1xD2xD3x0.523). D1, D2 and D3 are being the three maximal longitudinal, antero-posterior and transverse diameters, respectively (21). On the same day, a venous blood sample was obtained for the measurement of $\mathrm{AMH}, \mathrm{FSH}, \mathrm{LH}, \mathrm{E}_{2}$ and inhibin B.

Measurement of serum AMH levels was performed using the MIS/AMH enzyme-linked immunosorbent assay kit DSL (diagnostic systems laboratories, Inc./USA). Inhibin B was measured using the Inhibin B enzyme-linked immunosorbent assay kit (Diagnostic System Lab, Inc./USA). FSH, LH and $\mathrm{E}_{2}$ levels were assessed in plasma with the AxSYM immunoanalyser (Abbott Laboratories, Abbott Park, IL, USA).

Statistical analysis was performed using SPSS (version 13.0; SPSS, Inc., Chicago, IL). The data was expressed by means and the standard deviations. Relationship between two different continuous variables was assessed by Pearson Correlation. The Fisher $r$ to z-test was used to determine if the coefficient of correlation ( $r$ ) was significantly different from zero. A p $<0.05$ was considered as statistically significant.

\section{Results}

The mean age of the participants was 29.18 \pm 5.54 (range $23-44)$ and $69.5 \%(n=98)$ of the patients had primary infertility. The mean $\mathrm{AMH}$ and total AFC on day 3 were $2.23 \pm 1.90$ and $8.35 \pm 2.83$, respectively. Table 1 summarizes age, BMI mean of the $\mathrm{FSH}, \mathrm{LH}, \mathrm{E}_{2}, \mathrm{AMH}$, inhibin $\mathrm{B}$ and total $\mathrm{AFC}$ and the mean ovarian volume of the participants.

Correlations of the number of antral follicles, the mean ovarian volume, $\mathrm{AMH}$ and the others ovarian reserve parameters are shown in Table 2. Unlike, inhibin B, serum levels of $\mathrm{E}_{2}$ and $\mathrm{LH}$ $(\mathrm{r}=0.154, \mathrm{p}=0.06 ; \mathrm{p}=0.31 ; \mathrm{r}=-0.085$ and $\mathrm{r}=0.067, \mathrm{p}=0.42)$, those of age, $\mathrm{AMH}$, and FSH were significantly correlated with the number of early antral follicles on cycle day 3 .

It is noteworthy that the correlation between number of early antral follicles and serum AMH levels $(r=0.467, p<0.0001)$ was significantly stronger $(\mathrm{p}<0.0001)$ than age and serum levels of FSH $(r=-0.400, p<0.001 ; r=-0.299, p<0.001$ respectively $)$. In addition to this, serum AMH levels showed a stronger correlation $(\mathrm{p}<0.001)$ with the mean ovarian volume $(\mathrm{r}=0.373$, $\mathrm{p}<0.0001)$ than did those of age $(\mathrm{r}=-0.182, \mathrm{p}=0.03)$, inhibin $\mathrm{B}$ $(r=0.180, p=0.03), E_{2}(r=0.079, p=N S)$, FSH $(r=-0.276, p=0.001)$ and $\mathrm{LH}(\mathrm{r}=-0.005, \mathrm{p}=\mathrm{NS})$. Incidentally, serum AMH levels were significantly correlated with those of age $(r=-182, p=0.03)$, inhibin B $(r=0.259, \mathrm{p}=0.002)$ and FSH $(r=-0.290, \mathrm{p}<0.001)$, but not with those of $\mathrm{E}_{2}$ and $\mathrm{LH}$.

Table 1. The demographics and FSH, LH, $\mathrm{E}_{2}, \mathrm{AMH}$, Inhibin $B$, and $A F C$ and the mean ovarian volume on day 3 of the participants

\begin{tabular}{|l|c|c|}
\hline $\mathbf{n}=1 \mathbf{4 1}$ & Mean & $\mathbf{\pm S D}$ \\
\hline Age (years) & 29.18 & 5.54 \\
\hline BMI $\left(\mathrm{kg} / \mathrm{m}^{2}\right)$ & 24.76 & 3.90 \\
\hline FSH (IU/L) & 6.81 & 3.35 \\
\hline LH (IU/L) & 3.77 & 2.10 \\
\hline $\mathrm{E}_{2}(\mathrm{pg} / \mathrm{ml})$ & 41.28 & 21.29 \\
\hline Inhibin B (pg/ml) & 53.87 & 40.02 \\
\hline AMH (ng/ml) & 2.23 & 1.90 \\
\hline Total AFC (n) & 8.35 & 2.83 \\
\hline Mean ovarian volume & 5.44 & 2.31 \\
\hline
\end{tabular}

Table 2. Correlations of the number of antral follicles, the mean ovarian volume, $\mathrm{AMH}$ and the others ovarian reserve parameters

\begin{tabular}{|c|c|c|c|c|c|c|}
\hline \multirow[t]{2}{*}{ Parameters } & \multicolumn{2}{|c|}{ AFC } & \multicolumn{2}{|c|}{$\begin{array}{c}\text { The Mean Ovarian } \\
\text { Volume }\end{array}$} & \multicolumn{2}{|c|}{$\mathrm{AMH}$} \\
\hline & $\mathbf{r}$ & $\mathbf{p}$ & $\mathbf{r}$ & $\mathbf{p}$ & $\mathbf{r}$ & $\mathbf{p}$ \\
\hline Age (years) & -0.40 & $<0.0001 * *$ & -0.18 & $0.03 *$ & -0.18 & $0.03 *$ \\
\hline FSH (IU/L) & -0.29 & $<0.0001^{* *}$ & -0.27 & $0.001 * *$ & -0.29 & $<0.001 * *$ \\
\hline LH (IU/L) & 0.06 & 0.42 & -0.05 & 0.94 & 0.13 & 0.11 \\
\hline $\mathrm{E}_{2}(\mathrm{pg} / \mathrm{ml})$ & -0.08 & 0.31 & 0.07 & 0.34 & -0.42 & 0.62 \\
\hline Inhibin B (pg/ml) & 0.15 & 0.06 & 0.18 & $0.03 *$ & 0.25 & $0.002 * *$ \\
\hline $\mathrm{AMH}(\mathrm{ng} / \mathrm{ml})$ & 0.46 & $<0.0001 * *$ & 0.37 & $<0.0001 * *$ & 1 & \\
\hline
\end{tabular}




\section{Discussion}

The count of the number of antral follicles by ultrasonography is the best predictor for the quantitative aspect of ovarian reserve (22). There is no consensus on identification of the antral follicles (2), however several evidence based studies suggested to select the follicles as antral follicles based on a diameter measurement as 2 to $10 \mathrm{~mm}$. (3-10). It has been reported that human antral follicles measuring $<6 \mathrm{~mm}$ express the greatest amount of $\mathrm{AMH}$, and that levels decline with antral follicles increase in size (23). Two to six mm antral follicles were defined as AFC in our study. We observed that serum AMH levels are strongly related to early $\mathrm{AFC}$, with a significance that was remarkably stronger than age, serum levels of inhibin B, $\mathrm{E}_{2}, \mathrm{FSH}$ and LH. Similar results were found by the previous published studies about the relationship between $\mathrm{AMH}$ and antral follicle count and the coefficients of correlation were reported as stronger (0.71-0.74) than present study $(0.46)(24,25)$. The correlation of AMH and the different sizes of antral follicle was studied previously; the best correlation was found between AMH and $>5$ to $6 \mathrm{~mm}$ size of AFC and correlation coefficient ( $\mathrm{r}$ ) was reported as low as 0.41 . These different results may be explained by the lack of an international assay standard for AMH measurements.

In our results; a negative relationship was observed between FSH and total AFC and the ovarian volume. These data confirms the hypothesis of a stimulating role of FSH on granulosa cells on the antral follicle, caused by the dependency of FSH levels on the negative feedback from $\mathrm{E}_{2}$ and possible different regulation of AMH as compared with other hormonal parameters. Although little is known about FSH effects on $\mathrm{AMH}$ expression during the early follicular phase, it can be presumed that this hormone is less FSH-sensitive than inhibin $\mathrm{B}$ and $\mathrm{E}_{2}$.

On the contrary of previous reports; no correlations were detected between total $\mathrm{AFC}$ and inhibin $\mathrm{B}$ and $\mathrm{E}_{2}$ levels in this study. This result could be explained by the modulator role of FSH for inhibin $\mathrm{B}$ and $\mathrm{E}_{2}$. During the luteal-follicular transition, the secretion of inhibin $B$ and $E_{2}$ by the early antral follicles modulates their own stimulation by FSH $(26,27)$. This implies that inhibin $B$ and $E_{2}$ levels depend not only on the bulk of active granulosa cells available, as represented by follicular number and sizes, but also on their stimulation by FSH. There are potential advantages of using AMH over AFC or the other parameters because $\mathrm{AMH}$ can be measured throughout the cycle, in contrast to the other parameters, which can only be determined in the early follicular phase $(28,29)$. Therefore, AMH may represent a more independent and reliable marker of early antral follicle activity than inhibin $\mathrm{B}$ and $\mathrm{E}_{2}$, and FSH on cycle day 3 . As a conclusion, our results indicate that serum AMH levels are strongly related with ovarian follicular status during the early follicular phase, and also this relationship is more significant than other ovarian reserve parameters. These results also indicate that, serum AMH measurement is better predictor for the number of early antral follicles than conventional hormone measurements. This point may be helpful to refine future clinical applications of AMH measurements in routine infertility work-up for evaluating the fertility potential and monitoring infertility treatments.

\section{Conflict of interest}

No conflict of interest is declared by authors.

\section{References}

1. te Velde ER, Scheffer GJ, Dorland M, Broekmans FJ \& Fauser BC. Developmental and endocrine aspects of normal ovarian aging. Molecular and Cellular Endocrinology 1998; 145: 67-73.

2. Hendriks DJ, Mol BW, Bancsi LF, te Velde ER, Broekmans FJ, Antral follicle count in the prediction of poor ovarian response and pregnancy after in vitro fertilization: a meta-analysis and comparison with basal follicle-stimulating hormone level, Fertil Steril 2005; 83: 291-301.

3. Bancsi LF, Broekmans FJ, Eijkemans MJ, de Jong FH, Habbema JD, te Velde ER. Predictors of poor ovarian response in in vitro fertilization: a prospective study comparing basal markers of ovarian reserve, Fertil Steril 2002; 77: 328-36.

4. Chang MY, Chiang $\mathrm{CH}$, Hsieh TT, Soong YK, Hsu KH. Use of the antral follicle count to predict the outcome of assisted reproductive technologies, Fertil Steril 1998; 69: 505-10.

5. Nahum R, Shifren JL, Chang Y, Leykin L, Isaacson K, Toth TL. Antral follicle assessment as a tool for predicting outcome in IVFis it a better predictor than age and FSH?, J Assist Reprod Genet 2001; 18: 151-5.

6. Haadsma ML, Bukman A, Groen H, Roeloffzen EM, Groenewoud ER, Heineman MJ et al. The number of small antral follicles (2-6 $\mathrm{mm}$ ) determines the outcome of endocrine ovarian reserve tests in a subfertile population, Hum Reprod 2007; 22: 1925-31.

7. Sharara FI, McClammrock HD. Antral follicle count and ovarian volume predict IVF outcome, Fertil Steril 2000; 74: 176- 80.

8. Hsieh YY, Chang CC, Tsai HD. Antral follicle counting in predicting the retrieved oocyte number after ovarian hyperstimulation, J Assist Reprod Genet 2001; 18: 320-4.

9. Frattarelli JL, Levi AJ, Miller BT, Segars JH. A prospective assessment of the predictive value of basal antral follicles in in vitro fertilization cycles, Fertil Steril 2003; 80: 350-5.

10. Jayaprakasan D, Deb S, Batcha M, Hopkisson J, Johnson I, Campbell $\mathrm{B}$, et al. The cohort of antral follicles measuring 2-6 mm reflects the quantitative status of ovarian reserve as assessed by serum levels of anti-Müllerian hormone and response to controlled ovarian stimulation. Fertil Steril, Epub 2010; 94: 1775-81.

11. Avril C, Antral follicle count and oocyte quality, J Gynecol Obstet Biol Reprod 2006; 35: 42-3.

12. Van Rooij IA, Tonkelaar I, Broekmans FJ, Looman CW, Scheffer GJ, de Jong $\mathrm{H}$ et al., Anti-mullerian hormone is a promising predictor for the occurrence of the menopausal transition, Menopause 2004; 11: 601-6

13. Van Rooij IA, Broekmans FJ, Scheffer GJ, Looman CW, Habbema $\mathrm{JD}$, de Jong $\mathrm{H}$ et al. Serum antimullerian hormone levels best reflect the reproductive decline with age in normal women with proven fertility: a longitudinal study, Fertil Steril 2005; 83: 979-87

14. Fanchin R, Schonauer LM, Righini C, Frydman N, Frydman R, Taieb J. Serum anti-Mullerian hormone dynamics during controlled ovarian hyperstimulation, Hum Reprod 2003; 18: 328-32

15. Seifer DB, Mac Laughlin DT, Christian BP, Feng B, Shelden RM. Early follicular serum mullerian-inhibiting substance levels are associated with ovarian response during assisted reproductive technology cycles, Fertil Steril 2002; 77: 468-71.

16. Baarends WM, Uilenbroek JT, Kramer P, Hoogerbrugge JW, van Leeuwen EC, Themmen AP et al. Anti-müllerian hormone and antimüllerian hormone type II receptor messenger ribonucleic acid expression in rat ovaries during postnatal development, the estrous cycle, and gonadotropin-induced follicle growth, Endocrinology 1995; 136: 4951-62.

17. Durlinger LL, Gruijters MJG, Kramer P, Karels B, Kumar TR, Matzuk MM et al. Anti-Mullerian hormone attenuates the effects of FSH on follicle development in the mouse ovary, Endocrinology 2001; 142: 4891-9. 
18. Durlinger LL, Gruijters MJG, Kramer P Karels B, Ingraham HA, Nachtigal MW et al. Anti-Mullerian hormone inhibits initiation of primordial follicle growth in the mouse ovary, Endocrinology 2002; 143: 1076-84.

19. Ficicioglu C, Kutlu T, Baglam E, Bakacak Z. Early follicular antimüllerian hormone as an indicator of ovarian reserve, Fertil Steril 2006;85: 592-6.

20. Silberstein T, MacLaughlin DT, Shai I, Trimarchi JR, LambertMesserlian G, Seifer DB et al. Müllerian inhibiting substance levels at the time of HCG administration in IVF cycles predict both ovarian reserve and embryo morphology, Hum Reprod 2006; 21: 159-63.

21. Sharara FI, McClamrock HD. The effect of aging on ovarian volume measurements in infertile women. Obstet. Gynecol.,1999; 94, 57-60.

22. Scheffer GJ, Broekmans FJ, Looman CW, Blankenstein M, Fauser $\mathrm{BC}$, de Jong $\mathrm{FH}$ et al. The number of antral follicles in normal women with proven fertility is the best reflection of reproductive age. Hum Reprod 2003: 18: 700-6.

23. Weenen C, Laven JS, von Bergh AR, Cranfield, M, Groome NP, Visser JA et al., Anti-Mullerian hormone expression pattern in the human ovary: potential implications for initial and cyclic follicle recruitment. Mol Hum Reprod 2004; 10: 77-83.
24. de Vet A, Laven, JS, de Jong FH, Themmen AP, Fauser BC. Antimullerian hormone serum levels: a putative marker for ovarian aging. Fertil. Steril 2002: 77: 357-62.

25. Fanchin R, Schonäuer LM, Righini C, Guibourdenche R, Taieb J. Serum anti-Müllerian hormone is more strongly related to ovarian follicular status than serum inhibin B, estradiol, FSH and LH on day 3. Hum Reprod 2003; 18: 323-7.

26. Welt CK, Martin KA, Taylor AE, Lambert-Messerlian GM, Crowley WF, Jr, Smith JA, et al. Frequency modulation of follicle-stimulating hormone (FSH) during the luteal-follicular transition: evidence for FSH control of inhibin B in normal women. J. Clin. Endocrinol. Metab. 1997; 82: 2645-52.

27. Mais V, Cetel NS, Muse KN, Quigley ME, Reid RL, Yen SS. Hormonal dynamics during luteal-follicular transition. J. Clin. Endocrinol. Metab 1987: 64; 1109-14.

28. JK Hehenkamp, CWN Loomans, APN Themmen, FH de Jong, ER te Velde, FJM Broekmans. Anti-Mullerian hormone levels in the spontaneous menstrual cycle do not show substantial fluctuation, J Clin Endocrinol Metab 2006; 10: 4057-63.

29. A. La Marca, G. Stabile, AC Artenisio, A Volpe. Serum anti-Mullerian hormone throughout the human menstrual cycle, Hum Reprod 2006; $21: 3103-7$. 